\title{
Microcredit As A Tool For Rural Development: A Case Study Of Malaysia
}

Wali I. Mondal, Ph.D., National University, USA

\begin{abstract}
Malaysia is a prosperous country in Southeast Asia with two distinct geographical sections separated by the China Sea. Because the country has one of the lowest poverty rates of any developing country with 5.1 per cent of its population living below the poverty line, microcredit projects which are typically aimed at poverty alleviation, have not grown as rapidly as in other developing countries. However, microcredit and microfinancing lead to the growth of the microentrepreneur class in both rural and urban areas. Historically, of the 11 economic sectors of Malaysia, four sectors, namely Agriculture, forestry and fisheries; Mining and quarrying; Construction; and Wholesale and retail trade, hotels and restaurant did not grow at the rate of other economic sectors. A significant amount of economic activities of these four sectors take place in rural Malaysia. This was confirmed by the results of a Shift-Share analysis conducted by the author for the period of 2000-2005 and later compared with similar statistics for 2010. Using these results and comparing the success of microcredit in other developing countries, a case is made for sustained investment in microenterprises throughout rural Malaysia in the four sectors noted above.
\end{abstract}

Keywords: Microcredit Malaysia; Economic Development; Microenterprises

\section{INTRODUCTION}

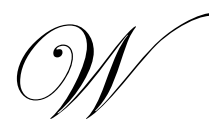

ith 13 states and 2 federal territories, Malaysia has a unique and diverse economy. The country has two geographical sections: Peninsular Malaysia and the Eastern Malaysian provinces of Sabah and Sarawak which are separated from the Peninsular Malaysia by the South China Sea. For administrative purpose, the country is divided into three economic regions: the provinces of Sabah and Sarawak, the East Coast Economic Region (ECER) consisting of the provinces of Kelantan, Terengannu, Pahang and Northern Johar and the remaining provinces of Peninsular Malaysia. Under able leadership and with a stable government, Malaysia has established itself as a high growth economy of the world; however, its government is still grappling with proper strategies for a balanced growth of all of its economic regions, especially a strategy to develop the rural areas of the country. The objective of this paper is to suggest a strategy to develop microentrepreneurship in the rural areas of the country.

In recent years, significant research has been conducted on the growth and development of entrepreneurship with the principal objective of maximization of profit. These studies are mostly growth-oriented and microeconomic in nature. More importantly, there is a severe dearth of research on the growth and development of microentrepreneurship for rural development. The emergence of microcredit has created a new class of entrepreneur known as the microentrepreneurs. Microcredit operation is intimately related to the concepts of microfinance, poverty alleviation and microentrepreneurship. While some of these concepts are still evolving and are being discussed in the development economics literature, the concept of microentrepreneurship flourished with the growth of microcredit in rural Bangladesh in the 1980s. Many developing countries have since adopted the collateral free microcredit model developed in the earlier part of the $20^{\text {th }}$ century by Rabindranath Tagore and popularized in Bangladesh with the creation of a specialized bank known as the Grameen Bank. In the following sections, a model of microentrepreneurship is developed, followed by an analysis of the economic sectors of Malaysia and their performance in the national economy. This analysis is followed by a discussion in favor of adoption of the microentrepreneurship model. In doing so, an attempt will be made to identify rural industries with 
unique industrial mix in all three economic regions of Malaysia and suggest a strategy for investment in these industries by microentrepreneurs. The five-factor model of Schumpeter will be used in identifying and analyzing the rural development potentials of the economic regions.

\section{ENTREPRENEURSHIP: ORIGIN AND EVOLUTION}

The term "entrepreneur" was first introduced in the Mercantilist age by Richard Cantillon (1680-1734). Schumpeter (1950) noted "Cantillon's work, which is usually, though not quite correctly described as the first systematic treatise on economics, then introduced the term "entrepreneur". Cantillon defined this entrepreneur as the agent who buys means of production at certain prices in order to combine them into a product that he is going to sell at prices that are uncertain at the moment at which he commits himself to his costs". (pp 253-54). The idea thus developed by Cantillon was incorporated into Say's Treatise on Political Economy (1821).

Say defined an entrepreneur as an agent who combines other resources into a "productive organism". He also used the term to indicate shifting of resources from a lower productive state to a higher productive state. It is important to note that Say did not incorporate the element of risk in his analysis of entrepreneurship although Cantillon alluded to it. Later, John Stuart Mill developed the concept further and associated entrepreneurship with activities involving risk and profit (Mill, 1871).

Although Mill incorporated risk in his analysis of profit and linked it to entrepreneurship, he, in fact was using the terms "entrepreneur" and "capitalist" synonymously. It appears that during most of the later nineteenth century, the two terms were used synonymously. Joseph Schumpeter is the first economist who distinguished between an entrepreneur and a capitalist (Schumpeter, 1939, 1950). According to him, assumption of risk involving innovation is the role of the entrepreneur, while assumption of risk involving potential for profit is the role of a capitalist. Both an entrepreneur and a capitalist undertake risk; but their domains are separate. Individuals who own business and take risk with their capital in pursuit of profit, but do not innovate, are capitalists. There are individuals who take risk by introducing a new product, adopting a new production process, creating new markets, introducing new technology or creating a new economic organization. Schumpeter referred to these individuals as "entrepreneurs" who belong to a "distinct sociological class". According to him, the process of discovery and innovation modifies the past and creates new opportunities for the creation of wealth in the future. This is what Schumpeter described as the process of "creative destruction".

\section{STATE OF KNOWLEDGE}

In recent years, a significant number of microcredit projects or microenterprises have become operational throughout the world. In almost all countries, women constitute over 90 percent of microenterprise owners; however, a void exists in literature regarding the definition of "microentrepreneurs". For example, an Internet search provides the following statement about microentrepreneurs:

Micro entrepreneurs are the owners of small businesses that have fewer than five employees and have startup costs of less than \$35,000 and annual revenue of less than \$100,000. There are nearly 21.5 million micro entrepreneurs in the U.S. Examples of micro entrepreneurs are owners of bakeries, beauty parlors, child care facilities, repair shops, arts and crafts shops, painting businesses, contracting businesses, family-owned shops, auto body shops, small-scale restaurants, and small-inventory trading businesses. (http://ezinearticles.com/?MicroEntrepreneurs\&id=353611)

While the number of 21.5 million microenterprises in the United States may be correct, all of them are not microentrepreneurs. Confusing capitalists with entrepreneurs (or in this instance, microenterprise owners with microentrepreneurs) was a common error that existed in economic literature until the epoch-making work of Joseph Schumpeter. According to Schumpeter, "the function of entrepreneur is to reform or revolutionize the pattern of production by exploiting an innovation or, more generally, an untried technological possibility for producing a new commodity or producing an old one in a new way, by opening up a new source of supply of materials or a new outlet for products, by reorganizing an industry..." (Schumpeter, 1950). He went on to attribute innovation as the 
business activity that brings about a new production function as a result of one or more of the following five economic activities:

1. introduction of a new good

2. adoption of new inputs to produce a new good or the previously produced good

3. introduction of new technology

4. $\quad$ opening of a new market; and

5. creating a new economic organization.

(Schumpeter, 1950; adapted from Mondal, 2002).

Schumpeter's theory of entrepreneurship stimulated extensive writing on the subject. Numerous studies have supported various sets of personality characteristics based on certain assumptions about behavior where sets of criteria, traits and personal principles and characteristics provide different types of insight. An approach now gaining more popularity explains entrepreneurship by combining economic, personal, and sociological variables. Personal characteristics, such as the need for achievement, risk-taking propensity, locus of control, beliefs about wealth and material gain, and business growth are related to a person's predisposition toward business leadership (Gartner, 1990, McDaniel, 2002). A belief that a person can influence his personal destiny and locus of control distinguishes entrepreneurs from the general population.

In reality, Schumpeter's model works through the transformation of a production function. A production function is the technological relationship between inputs and outputs. In other words, a production function refers to the methods and processes by which the factors of production namely land, capital and labor are combined by an entrepreneur for tangible output. This is where Schumpeter made a distinction between the terms invention and innovation. According to him, invention is discovery of new ideas, concepts, or material items that are normally confined to speculative reasoning. Such reasoning can be abstract and may remain uninvestigated in a scientific laboratory; however, if an invention in the form of an idea or a material item is transferred to the business sector with a view to changing the production function, then it becomes innovation.

\section{MICROENTREPRENEURSHIP}

Microentrepreneurship is related to the concepts of microcredit, microfinance, and poverty alleviation. With the success of microcredit operations in Bangladesh, microenterprises and microentrepreneurship have assumed a significant role in women's empowerment and poverty alleviation; however, the term microentrepreneurship is misinterpreted in the context of "microenterprise" or small business. The microfinancing approach has evolved as an economic development tool intended to benefit low-income women and men including the self-employed. Specialized lending institutions, known as Microfinance Institutes (MFIs) can be NonGovernmental Organizations (NGOs), savings and loan cooperatives, credit unions, government bank, commercial banks, or non-bank financial institutions. In Bangladesh, microfinance clients are typically self-employed, lowincome entrepreneurs in both urban and rural areas. Clients are often traders, street vendors, small farmers, service providers, and artisans and small producers, such as blacksmiths and seamstresses. Usually their activities provide a stable source of income (often from more than one activity). In addition to financial intermediation, many MFIs provide social intermediation services such as group formation, development of self-confidence, and training in financial literacy and management capabilities among members of a group. Thus the definition of microfinance often includes both financial intermediation and social intermediation - it is not simply banking, it is a development tool.

Microfinance activities usually involve:

- Small loans, typically for working capital

- Informal appraisal of borrowers' investment proposals

- $\quad$ Collateral substitutes, such as group guarantees or compulsory savings

- $\quad$ Access to repeat and larger loans, based on repayment performance

- $\quad$ Streamlined loan disbursement and monitoring 
- $\quad$ Secure savings products

Since the 1990s, there has been a rapid growth of MFIs worldwide. This growth coupled with a near perfect loan recovery rate has been accompanied by development of a variety of loan products offered by individual MFIs. The number of borrowers increased manifold. All borrowers do not fall into the same category. In most instances, MFIs make a distinction of borrowers and offer differentiated loan products to different groups. For example, ASA (pronounced "Asha"), an NGO in Bangladesh offers two types of loans: small loan and small business loan. The size of the initial small loan is comparable to similar microloans offered by other MFIs. It is offered to landless and assetless women. On the other hand, the small business loan is significantly larger in size. This loan is offered to an existing business. The existing business may need the additional capital to either expand its operation or to buy equipment for modernizing its product or to explore new markets for an existing product. Other resourceful MFIs also differentiate between borrowers along the same general line as ASA. The borrowers of MFIs, therefore, may be classified as:

\section{- $\quad$ Microborrowers}

- $\quad$ Microentrepreneurs

The microborrowers fall in the class of capitalists whose goal is to generate increasing income opportunities. These are borrowers who demonstrate a willingness and ability to generate a steady flow of income through conventional sources such as trading or paddy husking. There is no significant risk involved in the income generating activities of the microborrowers. Their labor is the predominant input, which is supplemented by a stock of capital in the form of a microcredit. The microborrower's ability to repay the loan is evaluated jointly with other members of the group.

A microentrepreneur usually owns a microenterprise and is engaged in innovating new ways of doing business or initiating changes in the production function, exploring market opportunities for his or her product and, ultimately changing the culture of doing business. Assumption of risk is the principal element of entrepreneurship. Not all microenterprise owners are microentrepreneurs. Also the missions of many microenterprises are not related to assuming risk with a goal to initiating changes in the production function. For example, In the United States, San Diego based Women's Empowerment International (WE) states it "has a simple and direct mission. It provides microcredit loans as small as $\$ 50$ to very poor women so they can start businesses and create new and better lives." The organization further states, "Our goal is to help the 3 billion people in our world who live on $\$ 2$ a day or less." (http://womenempowerment.org/). The mission of overwhelming majority of microenterprises, however, is to generate profit while helping poor clients.

\section{MALAYSIAN ECONOMY AND GROWTH POTENTIAL OF MICROENTREPRENEURSHIP}

The Government of Malaysia publishes annual GDP statistics by industrial origin. The national economy is divided into 11 sectors or industries: Agriculture, forestry and fishing; Mining and quarrying; Manufacturing; Construction; Services; Electricity, gas and water; Wholesale and retail trade, hotels and restaurants; Transport, storage and communication; Finance, insurance, real estate and business services; Other services (includes community, social and personal services, private non-profit services of households and domestic service of households); and Government services. For accounting purposes, the GDP calculation also incorporates imputed bank services, which are subtracted from the industrial contributions, and import duties, which are added to the industrial contributions. Malaysia has outperformed many developing economies in GDP growth. The country posted a steady growth rate during 2000-2008 but its GDP growth was negative in 2009 due to global economic crisis; however, aided by the government's stimulus package, the economy of Malaysia rebounded in 2010 showing an impressive growth rate of 7.2\%. (http://www.btimes.com.my/articles/20110218170948/Article/)

Like all countries, GDP growth in all economic sectors in Malaysia is not impressive. Many sectors show a rate of growth which is less than the national growth rate. Using a simple growth model known as the Shift-Share model (SS model), Mondal (2008) decomposed the growth of GDP in all 11 economic sectors of Malaysia during 2000-2005. The total growth of GDP was broken down into two components: growth due to the national economy (NG); and growth due to the unique industrial mix of an economic sector (IM). The advantages of decomposing the 
growth of all economic sectors are two-fold. First, one can identify the varying growth rates in all economic sectors. Secondly, one can compare the growth of an economic sector to the national growth rate. A brief description of the model is provided below.

The Shift-Share approach is a relatively recent technique used in regional growth analysis which decomposes the growth of GDP, employment or income according to pre-determined characteristics. The following example provides an illustration of employment growth occurring in various communities. As Buck (1970) explains, the Shift-Share analysis recognizes that "the effect of a region's unique industrial structure on employment growth be isolated. The "shift" component of the technique measures the movement (or shift) of the local economy into faster or slower growth sectors, while the "share" component measures the larger or smaller share of the growth occurring in a given economic sector. This is done by separating the growth of employment in a particular sector into three components: the national growth (NG), the industrial mix (IM), and the competitive share (CS) components. The following definitions of the NG, the IM and the CS components, as applied to employment growth are adapted from Hustedde, Shaffer and Pulver (1984).

The national growth component measures the potential change in local employment, assuming the local economy is similar to the national economy. The national growth component is calculated by multiplying the base year employment in each sector by the national average employment growth rate, and then summing over all the sectors. The results show how many new jobs were created locally due to national economic trends, assuming the local and national economies are identical.

The second step in shift-share analysis is to compute the industrial mix component. The industrial mix component is determined by multiplying the local employment in each economic sector by the difference in the national growth rate for that sector and the growth rate for the whole economy. A positive industrial mix indicates that the majority of local employment is in sectors which are growing faster than national total employment. A negative industrial mix indicates just the opposite.

The competitive share component measures the ability of the local economy to capture an increasing (decreasing) share of a particular sector's growth. It is computed by multiplying the local employment in each economic sector by the difference in that sector's national and local growth rate. After doing this for all sectors, the results are summed to give the community share.

A positive competitive share indicates that the community gained additional jobs over those due to national growth and its industrial structure. This gain suggests that the community is more competitive (efficient) in securing additional employment than is the rest of the nation. It is important to examine the competitive share for both the community and particular sectors. Each yields different information. Symbolically,

$\mathrm{SS}=\mathrm{NG}+\mathrm{IM}+\mathrm{CS}$, and

$\mathrm{NG}=\Sigma\left[\left(\mathrm{E}_{\mathrm{oi}}\right) \delta\right]$

where,

$\mathrm{E}_{\mathrm{oi}}=$ Base year local employment in sector $\mathrm{i}$;

$\mathrm{i}=1,2 \ldots \mathrm{k}$ (number of sectors)

$\delta=$ National average employment growth rate;

$\mathrm{IM}=\Sigma\left[\left(\mathrm{E}_{\mathrm{oi}}\right)\left(\Omega_{\mathrm{i}}-\delta\right] ;\right.$

where,

$\Omega_{\mathrm{i}}=$ National employment growth rate in sector i;

and 
$\mathrm{CS}=\Sigma\left[\left(\mathrm{E}_{\mathrm{oi}}\right)\left(\Omega_{\mathrm{i}}-\beta_{\mathrm{i}}\right)\right] ;$

where,

$\beta_{\mathrm{I}}=$ local employment growth rate in sector i.

Because of lack of disaggregated local data, Mondal used the SS model to decompose employment growth due to the growth of the national economy, and due to the unique industrial mix of each economic sector. Since our goal is to identify sectors that historically lag behind national economy in terms of employment growth, the results of the analysis will be useful in identifying economic sectors with potentials for the growth of microentrepreneurship. For the purpose of this research, growth in 11 economic sectors of Malaysia will be analyzed for the period 2000-2005 and then contrasted with the growth rate in 2010. The choice of 2000-2005 was deliberately decided to analyze the sectoral growth of Malaysia's economy before launching of the National Development Agenda by the government in 2006.

The Shift-Share model discussed above was applied as a special case to the 11 economic sectors of Malaysia's national economy. In the absence of comparable data for disaggregated industry or the regional or provincial data, we are able to compute only two of the three components of the model, namely, the NG and the IM component. As will be shown below, the total growth in each sector will be a composite of the growth of the two components. The decomposition of the national data into these two components and the results are provided in Table 1:

Table 1: Malaysia's NG And IM Components By Industrial Origin, 2000-2005

\begin{tabular}{|l|c|c|c|c|}
\hline \multicolumn{1}{|c|}{ Sector } & $\begin{array}{c}\text { Base Year (2000) } \\
\text { GDP }\end{array}$ & $\begin{array}{c}\text { Growth } \\
\text { Rate (\%) }\end{array}$ & NG & IM \\
\hline Agriculture, forestry and fisheries & 18,662 & 15.88 & $4,574.06$ & -1610.53 \\
\hline Mining and quarrying & 15,385 & 13.77 & $3,770.86$ & $-1,652.35$ \\
\hline Manufacturing & 67,250 & 23.01 & $16,482.98$ & $-1,008.75$ \\
\hline Construction & 6,964 & 2.43 & $1,706.88$ & $-1,537.65$ \\
\hline Services & 113,408 & 34.53 & $27,796.30$ & $11,363.48$ \\
\hline Electricity, gas and water & 8,278 & 31.35 & $2,028.94$ & 566.22 \\
\hline $\begin{array}{l}\text { Wholesale and retail trade, hotels and } \\
\text { restaurant }\end{array}$ & 31,116 & 23.60 & $7,626.53$ & -283.16 \\
\hline Transport, storage and communications & 16,858 & 36.70 & $4,131.90$ & $2,054.99$ \\
\hline $\begin{array}{l}\text { Finance, insurance, real estate and business } \\
\text { services }\end{array}$ & 26,755 & 50.42 & $6,557.65$ & $6,932.22$ \\
\hline Other services & & & & \\
\hline Government services & 16,070 & 26.61 & $3,938.76$ & 337.47 \\
\hline
\end{tabular}

${ }^{1 .}$ In 1987 constant prices (RM million)

2. Community, social and personal services, private non-profit services of households and domestic service of households

Source of GDP data: Ministry of Finance and Department of Statistics, Malaysia

The NG and IM components of Table 1 may be interpreted as "potential contributions" of the respective sectors to the GDP of Malaysia due to national growth, and due to the unique industrial structure of a particular sector. The results show, of the 11 sectors, the IM component is negative in 5 sectors. It is because the growth rate of those 5 sectors was lower than that of the national average growth rate. The NG component is always positive since we assume that part of the growth in any sector is attributable to the national growth. The following example illustrates the point. During 2000-2005, the Finance, insurance, real estate and business services sector contributed 13,490 million RM to the GDP of Malaysia. Of this amount, 6,557.65 million RM was contributed by this sector due to national growth of the economy and 6,932.22 million RM was contributed by the unique industrial mix of the sector. These two components together accounted for the total growth. Because the third data point, either a disaggregated industry (such as insurance or real estate) or a regional or provincial economy component is absent, we could not compute the CS component; however, such deficiency would not hinder the broad results of this study. 
As seen in Table 1, during 2000-2005, five economic sectors of Malaysia lagged behind the national economy in terms of employment growth. These sectors are: Agriculture, forestry and fisheries; Mining and quarrying; Manufacturing; Construction; and Wholesale and retail trade, hotels and restaurants. The latest sectoral growth report for 2010 provides the following statistics of annual growth:

- $\quad$ Agriculture, forestry and fishing, $1.7 \%$,

- $\quad$ Manufacturing, $11.4 \%$

- $\quad$ Mining and quarrying, $0.2 \%$

- $\quad$ Construction, $5.2 \%$

- Wholesale and retail trade, hotels and restaurants, $5.3 \%$

The above analysis suggests that four economic sectors, namely Agriculture, forestry and fisheries; Mining and quarrying, Construction; and Wholesale and retail trade, hotels and restaurants have historically underperformed in employment growth and their contributions to the GDP. Except for Construction, the other three sectors are predominantly inhabited by rural populations. Any strategy of rural development of Malaysia should be based on this historical fact.

\section{RURAL DEVELOPMENT THROUGH MICROENTREPRENEURSHIP IN MALAYSIA}

Microfinancing is gradually assuming importance importance as a strategy of rural development in Malaysia. In July 2009, the Finance Ministry extended permission to international banks operating in Malaysia to provide microcredit financing. (http://www.afminetwork.org/en/news/163/international-banks-can-now-financemicrocredit-in-malaysia.html). There are microenterprise projects assisted by the United Nations Development Program (UNDP) and other agencies with specific missions of increasing communication strategies and awareness and women's empowerment (http://www.undp.org.my/entrepreneurial-skills-empowering-women); however, the number and scope of such projects need to be widened. Funding for these projects seems to be inadequate for the needs of the rural population. Many developing countries of the world including Bangladesh, India and Indonesia have adopted microfinancing as a tool of poverty alleviation and rural development. Microcredit projects generate significant positive externalities that include improvement of rural infra-structure, creation of new markets in the rural areas, and most importantly, creation of a class of microentrepreneurs. Malaysia has a unique economy where on part of the country is separated from the mainland by the China Sea. This geographical phenomenon calls for development of those industries which would support the local economy. As a country, Malaysia can pride itself with one of the lowest rate of population below poverty line, estimated at $5.1 \%$ in 2009 . This indicates investment in rural industries, particularly those that have a lower growth rate than the national average, carries the prospect of creating a microentrepreneur class.

\section{AUTHOR INFORMATION}

Dr. Wali I. Mondal is a Professor of Business at National University in La Jolla, California where he also served as Interim Dean during 2006-07 and 2007-08 academic years. Mondal received his Ph.D. from the Ohio State University and has been a full time faculty for over 28 years. During 1993-96, he served as the Chair of the Department of Accounting, Economics and Business Education at Henderson State University. He has published a scholarly book, book chapter and over 70 papers in national and international refereed journals. Professor Mondal is the founding President and Conference Chair of the American Society of Business and Behavioral Sciences (ASBBS www.asbbs.org ). He is also the Editor or Editor-in-Chief of 5 national and international journals. E-mail: wmondal@nu.edu

\section{REFERENCES}

1. Brown, A. J. (1969), "Surveys of Applied Economics: Regional Economics With Special Reference to the U.K.," Economic Journal 74, 759-796

2. Buck, T.W. (1969), "Shift and Share Analysis-A Guide to Regional Policy?" Regional Studies 4,445-450.

3. Curtis, Wayne C. (1972), "Shift-Share Analysis as a Technique in Rural Development," American Journal of Agricultural Economics 54, 267-270. 
4. Dunn, E.S., Jr. (1960), “A Statistical and Analytical Technique for Regional Analysis,” Regional Science Paper Proceeding 6, 97-109.

5. Hustedde, R., R. Shaffer and G. Pulver (1984), Community Economic Analysis: A How-to Manual. Ames, IA: North Central Regional Center of Rural Development (Iowa State University).

6. Leser, C.E.V. (1951), "Some Aspects of the Industrial Structure of Scotland," University of Glasgow Dept. of Social and Economic Research, Occ. Paper V (University of Glasgow).

7. Malaysia. Ministry of Finance and Department of Statistics, various years.

8. Mills, John Stuart. 1848. Principles of Political Economy. London: Macmillan Press.

9. Mondal, Wali I. 2009. Poverty Alleviation and Microcredit in Sub-Saharan Africa, International Business and Economics Research Journal, Vol. 8, No 1, January 2009; pp 1-10

10. 2008. A Model to Analyze The Economic Development Potential of The East Coast of Malaysia: A Shift-Share Approach. Keynote paper delivered at the ECER 2008 Conference, Kota Bahru, Malysia; December 2008.

11. 2005.Microcredit and Microentrepreneurship: An Extension of Schumpeters Five-Factor Model AIUB Journal of Business and Economics, Vol. 4, No. 2, August, 2005

12. 2002. Microcredit and Microentrepreneurship Collateral Free Loan at Work in Bangladesh, Academic Press, Bangladesh, 2002; ISBN 984-32-0284-8; October 2002

13. Say, J.B. 1821. A Treatise on Political Economy. (Translated by C.R. Princep). Boston: Wells and Lilly (originally published in 1803).

14. Schumpeter, Joseph A. 1950. Capitalism, Socialism and Democracy. New York: Harper and Sons.

15. 1939. Business Cycles: A Theoretical, Historical, and Statistical Analysis of the Capitalist Process. New York: McGraw-Hill.

16. 1936. The Theory of Economic Development: An Inquiry into Profits, Capital Credit, Interest and the Business Cycle. Cambridge, MA: Harvard University Press

\section{INTERNET REFERENCES}

1. http://ezinearticles.com/?Micro-Entrepreneurs\&id=353611

2. $\quad$ http://womenempowerment.org

3. $\quad$ http://www.btimes.com.my/articles/20110218170948/Article/

4. http://www.afminetwork.org/en/news/163/international-banks-can-now-finance-microcredit-inmalaysia.html

5. $\quad$ http://www.undp.org.my/entrepreneurial-skills-empowering-women 